\section{Malignancy induced haemophagocytosis by erthroid cells and its transformation into a multinucleated giant cells - A unique clinical image}

\author{
Prachi $^{1 *}$, Gaurav Sharma ${ }^{2}$ and Suparno Chakrabarti ${ }^{3}$
}

\begin{abstract}
${ }^{1}$ Senior Resident, Department of Pathology, Dharamshila Narayana Superspeciality Hospital, New Delhi, India

${ }^{2}$ Senior Consultant, Department of Pathology, Dharamshila Narayana Superspeciality Hospital, New Delhi, India

${ }^{3}$ Senior Consultant and Head of the Department of Haematoncology and Bone Marrow Transplant, Dharamshila Narayana Superspeciality Hospital, New Delhi, India
\end{abstract}

Haemophagocytosis is a dysregulated immune condition characterised by both inflammation and uncontrolled activation of macrophages and T-cells, which causes aberrant cytokine release, leading to cytokine storm [1] it can be primary or secondary, depending upon the etiology.

We present a case in a 23 years old female presented with complaints of spontaneous ecchymotic patches over legs \& arms for 10 days, gum bleeding and menorrhagia. On evaluation no evidence of gum hyperytophy, lymphadenopathy and hepato-splenomegaly noted. Her investigations on admission showed pancytopenia picture. She was evaluated with bone marrow examination and flowcytometry. Her bone marrow aspirate depicted acute

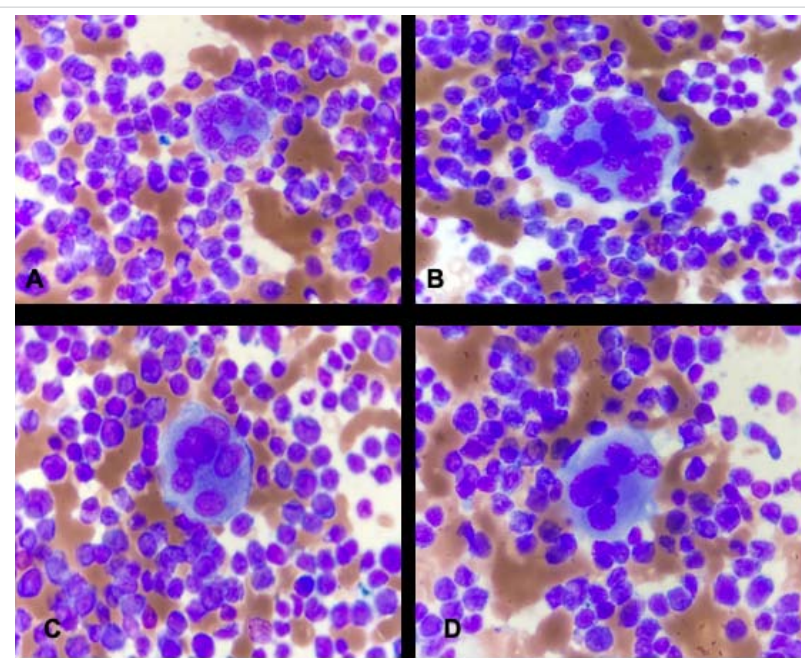

Figure 1: A-D: The microphotograph depicts Malignancy induced Haemophagocytosis by erythroid cells of lymphocytes, monocytes and blasts cells and its transformation into a multinucleated giant cell.
More Information

*Address for Correspondence: Dr. Prachi, Senior Resident, Department of Pathology, Dharamshila Narayana Superspeciality Hospital, New Delhi, India, Tel: 8006336230; Email: prachipath123@gmail.com

Submitted: July 24, 2021

Approved: July 26, 2021

Published: July 27, 2021

How to cite this article: Prachi, Sharma G, Chakrabarti S. Malignancy induced haemophagocytosis by erthroid cells and its transformation into a multinucleated giant cells A unique clinical image. J Clin Med Exp Images. 2021; 5: 007-007.

DOI: 10.29328/journal.jcmei.1001023 access article distributed under the Creative Commons Attribution License, which permits unrestricted use, distribution, and reproduction in any medium, provided the original work is properly cited.

(W) Check for updates

OPEn Access
Copyright: @ 2021 Prachi, et al. This is an open

myeloid leukemia in the background of myelodysplastic Syndrome showing a unique finding of Haemophagocytosis by erythroid cell of blast, lymphocytes and monocytes and its transformation into multinucleated giant cell, which is unique finding in this case. On Next Genome Sequencing, it was found to be associated with PTPN11 gene mutation on chromosome 12.

It is mandatory to note this finding as it helps in tailoring the line of management. Usually such patients have failure of induction therapy.

Our main aim is to identify this unique finding in cases of Acute Myeloid Leukemia, which has not been reported in the literature till date.

\section{Acknowledgements}

I would like to acknowledge the entire technical staff of haematology and bone marrow transplant unit, dharamshila Narayana Superspeciality hospital, New Delhi- 110092.

Ethical Approval: Taken

Consent: Obtained

Guarantor: Dr. Prachi.

\section{References}

1. Janka GE. Hemophagocyticsyndromes. Blood Rev. 2007;21:245-253. PubMed: https://pubmed.ncbi.nlm.nih.gov/17590250/ 